\title{
Environmental Education and Tourism
}

Joana Padrão

USC-ES

(joanapadrao@hotmail.com)

Joana Tavares

U. VIGO- ES

\section{DOI:10.5901/mjss.2014.v5n22p540}

\section{Abstract}

One aspect that seems to mark the tourist demand in recent years relates to a trend (confirmed by statistics) called for increased environmental tourism. This fact brings new challenges to the tourist agents who still are confronted with increasingly demanding and diverse public. It should be noted that the environmental tourism, assumes a set of commitments not only from the environment itself as for individuals. For this it is necessary to develop an environmental awareness that allows, despite increased human presence in a "place" does not deface the nature of that space. Rather, environmental tourism and environmental ecology are presented as two sides of the same coin in that based on the same concerns of ecological, environmental and human and the same assumptions of conservation, sustainability and social responsibility. Thus, the greatest human presence that follows the development of this type of tourism should be reflected, not detract from the tourist destination but a greater investment in the preservation, conservation and respect for the uniqueness of that destination.

Keywords: Environmental tourism, Environmental Education, Sustainability

\section{Introduction}

Our planet has been going through profound technological and scientific changes. The ecological imbalances within ecosystems, foreshadow the livelihood of life on Earth, but are attenuated by sustainability. Environmental deterioration has been reaching numbers never before witnessed.

According to research conducted by NASA from the beginning of the twentieth century, the Earth's temperature has increased $1,8^{\circ} \mathrm{C}$, boosted by increased emissions of gases that lead to greenhouse gases and air pollution, which is intensified with the growth of industrialization. Have the World Wildlife Fund (WWF), indicates that approximately $35 \%$ of Europe's ecosystems have been severely modified by acid rain. The Food and Agriculture Organization (FAO) states that all days are destroyed forests. Only between 1981 and 1990 were felled, equivalent to 30\% of Amazonian rainforests.

Nowadays tourism is seen as a strong and influential activity to both economic, political, environmental and socio-cultural level. Although tourism is usually associated with increased urban development, focused on consumption, fun and pleasure, this reality has been changing itself, and thus tourism has come to manifest itself in an important "social agent", such that, in many cases tourism becomes the main responsibility for the development of certain crops and regions (Júnior, 1997; Silveira, 2002; Marujo, 2008).

Nevertheless, it is essential that this activity is thought out and planned in a sustainable manner, ensuring consistency between economic development and environmental conservation.

"There is no real answer to the ecological crisis unless on a global scale and with the proviso that operates an authentic political, social and cultural revolution, reorient the goals of the production of material and immaterial goods. This revolution should therefore concern not only the relations of visible forces on a large scale, but also the molecular areas of sensitivity, intelligence and desire " (Guattari, 1991: 9).

With this study we intend to demonstrate the importance of environmental education in the bet for strengthening a sustainable tourism and consequently to preserve the environment for future generations. 
It is still a preliminary study in which it is intended primarily to reflect on the possibilities and potentialities of the articulation of these two areas: Tourism and Education.

\section{Tourism and the environment}

Tourism has been assumed as a major factor in environmental degradation, although lately the situation has been reversed, to harmonizing the gap that existed until then, with greater demand and interest in nature, local communities and their heritage but also in an attempt to escape from the big urban centers. However there is still a lack of responsibility on the part of tourists, as to the preservation of nature, tourist destinations. Therefore urges a focus on environmental education.

No one doubts, however, that the concept of sustainability and environmental issue certainly does not arouse interest to all tourists. It so often the destinations seek to harmonize both the economic interests such as the preservation of the environment. The concept of sustainable tourism will change with the passage of time since the world itself and society are changing.

The concept of sustainability arises in the twentieth century, where in the Brundtland report, states that sustainable development "is one that balances the imperative of economic growth with the promotion of social equity and preserving the natural heritage, thereby ensuring that the needs of current generations are met without compromising meet the needs of future generations". On the other hand, Swarbrooke (2002: 19) states: "that any definition of sustainable tourism emphasizes the environmental, social and economic elements of the tourism system" and that: "which could lead to a definition of what sustainable tourism means tourism that is economically viable, but not destroys the resources on which tourism in the future will mainly depend on the physical environment and the social fabric of the local community." (Swarbrooke, 2002: 19)

Generally, tourists always travel at the same time of year, are referred to as "the biggest offenders of natural spaces." (Ramos, 2004). When there is a large influx of tourists in one place, this target becomes crowded both in terms of equipment, transport and food, leading an assault on the landscape and the ecosystem itself.

So a whole prior planning is necessary because tourism is a major source of income for the people and a great enhancer of local development. According to Ramos (2004: 4), this planning should be done so as to avoid wear on the environment, "reducing the social costs that affect the residents of the regions visited and improving the benefits of tourism development, and its absence has negative consequences for tourist locations, causing nearly irreparable damage. "

However, some changes now seem to arise. Ruschmann (1997: 17) states that: "'soft' tourism, eco, naturalist, customized and conducted in small groups of people tends to characterize the tourist traffic of the future."

In this sense Ruschmann addresses the tourism planning as a set of measures and actions which you want to obtain greater detail and necessary to a better advantage of tourist destinations conditions, also consider going to their regional characteristics.

Talking about sustainability implies that all involved can benefit from this process. The main focus is no longer strictly economic to spend to be people-centered. When the tour is done only thinking about the economic aspect, without valuing its consequences, is to jeopardize the life of this place.

According to France (1997), sustainable tourism based on the following criteria:

. be ecologically sustainable and economically feasible;

distribute its benefits equitably;

. be ethical and socially accepted by the communities;

. integrate and respect the environment;

. encourage participation and cooperation of all in its planning;

. meet the tourist and encourages it, in the conservation of the environment and local culture;

. integrate into the local economy, promoting a better quality of life in communities;

. be properly planned, applying the principles of sustainability, either to transport, sanitation, electricity etc.).

. practice responsible marketing; 
ensure that their development is developed in accordance with the principles of sustainability (cultural authenticity, social inclusion, environmental conservation, quality of service and a good ability of local management) causing the least possible negative impact.

\section{Environmental education and tourism}

Environmental education is a requirement of the environmental crisis we are experiencing in contemporary times, and can be transmitted through formal and non-formal educational processes. The first process is set by the curricula of educational institutions, and the second is one that occurs outside of institutionalized environments through activities or environmental messages that inform and to educate without any actual perception of the subject on such a process, where you can enter some tourist activities.

Grimm, Loose and Sampaio (2013: 38), argue that environmental education "occupies a prominent place in the tourism production chain, since the tourist interacts with all elements directly or indirectly and, therefore, the educational practice can be conceived from all the elements that make up the tourism industry. "

It is in this perspective that tourism should promote environmental knowledge and education level, combining information and environmental actions through direct contact and / or experiences related to local natural heritage. Thus, it is believed that by creating opportunities for interaction with the tourist community, can provide new ways to circumvent environmental issues.

Therefore, the relationship between tourism based on criteria of sustainability and environmental education must aim to build public more supportive of tourists and people with responsible attitudes compared to spaces that visit. This environmental crisis makes it imperative that tourism is a driver of good environmental practices, promoting harmony between man (tourist) and nature, as well as an education bidirectional nature between man (tourist) and host who promotes the sharing of customs, roots and local culture.

Bearing in mind that, in contemporary societies, economic interests outweigh the environmental, we can say that tourism entails a social paradox, since that is the economic part that is the engine of this practice, but it is the environmental part that fits most tourist motivations (beach, countryside, mountains, etc..). Tourism is thus dependent on the use of the environment and should be set in the light of sustainability, ie it must use natural resources without compromising its capacity for renewal and conservation. It was perhaps the degradation of these natural spaces that currently starts a new form of tourism, in light of the design of emerging global village: a contemporary tourism-oriented nature, which is configured as a non-formal environmental education in order to remake relations man and nature. This is relearning senses to nature and awareness that environmental degradation results from human action and there is no way to save the environment if we do not change our behavior and our way of life.

Sauvé (2005) proposes the reconstruction of the feeling of belonging to nature, suggesting that environmental education privileges, formally or not, the closest relationship between man and the environment. Whether contemporary tourist or individuals of indigenous communities, have become increasingly demanding in seeking conniving tourist activities with the environment. In this sense, tourism has gradually adjust to in order to attend a public increasingly demanding and more oriented towards conservation and environmental protection consumer. We speak therefore of environmental tourism or ecotourism, whose activities can be very different, eg, hiking, biking, rafting, mountain biking, bird watching, etc. (Neiman \& Rabinovich, 2008).

Under this design, the tourist activity must transform the perception of tourists, contributing to the holistic education and awareness of environmental issues, and revealing the transformative potential of the travel experience of other cultures and ways of acting.

Barcelos (2012) refers to the importance of the affective and playful engagement that is triggered during the practice of tourism, noting that the lack of such involvement difficult to create roots for environmental education. According to Grimm, Loose and Sampaio (2013), experiments and experiences offered by tourism can generate reflections and questions about the nature-society relations, and the communities where tourism is projected, as well as globally. This is precisely the aim of environmental education. The same authors also say that social and educational experiences that go beyond the time of the visit and reach the daily lives of individuals through communication between people from different places and tourism for the environment can be generated.

Environmental education emerges from the experience lived during the tourist activities resulting in sensitization / awareness to the subject with the care and respect needed in human-nature relationship. 
One of the aspects we can point out the tourism-environment concerns the active participation of local community in the planning of tourism activities, which is directed to the protection of the local natural and cultural heritage (Swarbrooke, 2000; Santos \& Arantes, 2011). It is based on this assumption that highlights the importance of environmental education, and its broker the local population of the regions visited. Environmental education can only be systematically from the observations of the same agent, the same agent which os responsible for their applicability and application of appropriate indigenous community.

Cascino (2000) then states that environmental education should be seen as a shared responsibility, as it believes that the creation of ecotourism is the responsibility of concerned individuals to do something new. Environmental education must configure the sustainable tourism as an inter-relationship with the indigenous community and the environment, linking the consumption of space, natural and cultural heritage in a sustainable manner.

Grimm, Loose and Sampaio (2013: 39) state that "the effort to articulate the themes of tourism, communication, sustainability and environmental education part of the concerns arising from the dialogue of knowledge provided by interdisciplinary academic experience." The same authors state that the establishment of tourism can be sustainable in that other rationalities emerge and dialogue towards a new development of the communities where recetoras care are promoted and values that there has, because unique. Only thus promote "other worldviews, more integrative over society-nature relationship, permeating generations" (Grimm, Loose and Sampaio, 2013: 40).

According Ruschmann (1997) "citizen-tourist" must be educated to a conscious participation in protecting the environment not only during the holidays but also in everyday life when you are at your place of origin.

Machado and Morales (2010) say that tourism, from a local based, can be the creator of educators situations with environmental orientation characterized by questioning environmental issues and developing critical spirit. Also report that individuals of the visited the city, by participating and taking ownership of the tourism organization, can build different looks and develop new perceptions about the environment they live in, ie, educate themselves. And an share these other viewpoints and these new perceptions with tourists who visit them, also encourage them to transformative visions.

The same authors suggest a new approach to tourism in which the residents of the local community can (re)visit their own place of habitual residence, and thus counteract the usual characterization of tourism that involves physical movement to different places of dwelling. The only displacements that are observed here are the look, the understanding of the action.

This is an educational proposal that sets the light of social being in trials, experiences, reflections and critical look, rebuilding how society views social and environmental issues. Therefore, this approach aims not only transformations at an individual level but also at a collective level.

According to Rodrigues (2000) the sustainability of tourism must be socially constructed, stating that the big challenge is to build the utopia of a sustainable society.

\section{Method}

The methodology points the way of thinking and the practice exercised in approaching reality. Thus, the methodology of a research becomes a research tool by which the proposed problem is feasible in order to that the objectives are achieved (Minayo ,2001). In this study we have a bibliographic and documental research, for a theoretical study in depth by consulting books, journals, legislation, institutional documents and other available sources; review of literature pertinent to man and its relation to the environment, sustainable development, tourism, environmental education, ethics of responsibility, ecological literacy, citizenship and other aspects relevant to the topic.

\section{Discussion}

Tourism should enhance the preservation of the environment as well as improving and maintaining the quality of life of communities that are visited by tourists.

It is urgent to awake in people and tourists the ability to understand the environment, and the environment that surrounds them, but it is also necessary to call for a more active participation of all of us. When tourism is pondered only with the economic aspect, without valuing its consequences, can jeopardize the life period of this place.

Tourism, from a local based, can create new forms of environmental education to tourists and to the communities that are visited, by questioning environmental issues and developing critical spirit. The key for a successful education is the 
"sense of community", that can be characterized by unic relationships among community residents that share common interests. And by passing through this "sense of community" to tourists, this sense of protecting what belongs to us (NIMBY or NIABY), we can observe the great potential of this kind of revolutionary education: the transformative and productive tourism experiences, which are simultaneously an exploration of new cultures and the discovery of the joy experienced in nature.

Environmental education aims to outline guiding paths able to define a sustainable future, committed to the social, forming environmentally conscious and responsible citizens, not only to his generation but also to future generations.

\section{References}

Barcelos, V. (2012). Educação Ambiental - sobre princípios, metodologias e atitudes. 4ª Ed. Petrópolis- RJ: Vozes.

Cascino, F. (2000). Pensando a relação entre educação ambiental e turismo. Campinas, SP. Ed. Papirus, 2000

Guattari, F. (1991). As três ecologias. Tradução Maria Cristina F. Bittencourt; Revisão da tradução Suely Rolnik. - 3. Ed. Campinas: Papirus.

Grimm, I.; Loose, E. \& Sampaio, C. (2013). "Tourism, Communication and Sustainability: Reflections and Possibilities for Environmental Education". CAD. Est. Pes. Tur. 2, $26-42$.

Júnior, E. L. (1997). "Urbanização Turística, Cultura e Meio Ambiente”. In: Serrano, C- T. \& Brunhs, H. (orgs). Viagens à natureza, turismo, cultura e ambiente - Campinas, SP.Papirus.

Machado, R. \& Morales, R. (2010). Educação ambiental crítica e turismo pedagógico de base local nas visitas ao bairro Cabuçu, Guarulhos - SP. V Encontro Nacional da Anppas - 4 a 7 de outubro de 2010- Florianópolis - SC - Brasil

Marujo, M. (2008). Turismo e comunicação. Castelo Branco: RVJ editores.

Neiman, Z. \& Rabinovich, A. (2008). A Educação Ambiental através do Ecoturismo: o diferencial das atividades de contato dirigido com a natureza. Pesquisa em Educação Ambiental, vol. 3, n. 2 - pp. 77-101.

Ramos, G. C. (2004). "Turismo e meio ambiente". Tese de Bacharelado em Direito. São Paulo.

Ruschmann, D. (1997). Turismo e Planejamento Sustentável: a Proteção do Meio Ambiente. São Paulo: Papirus Editora.

Santos, R. \& Arantes, M. (2011). A educação ambiental como recurso de gestão e planificação: sua aplicabilidade no turismo. Revista Científica Eletônica de Turismo Ano VIII - Número 15.

Sauvé, L. (2005) Educação ambiental: possibilidades e limitações. Université du Québec à Montréal Educação e Pesquisa, São Paulo, v. 31, n. 2, p. 317-322.

Silveira, M. A. T. (2002). "Planejamento territorial e dinâmica local: bases para o turismo sustentável". In: Rodrigues, A. B. (Org.). Turismo e desenvolvimento .São Paulo: HUCITEC.

Swarbrooke, J. (2002). Turismo Sustentável: Conceitos e Impacto Ambiental. volume 1, 3a edição, São Paulo: Editora Aleph.

Swarbrooke, J. (2000). Turismo sustentável: meio ambiente e economia, vol. 2. Trad. Esther E. H., São Paulo: Aleph. 